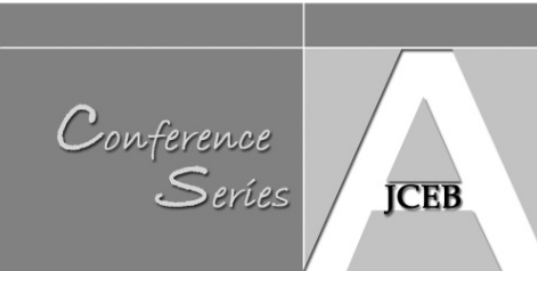

\title{
Management Challenges within Multiple Project Environments: Lessons for Developing Countries
}

Noor Ismah Hashim, Nicholas Chileshe, and Bassam Baroudi

(University of South Australia, Australia)

\begin{abstract}
In the construction industry, multiple project environments (MPE) exist where more than one project is managed simultaneously. The driving force behind MPEs is the pragmatic allocation of resources encumbered by uncertain economic times. However, MPEs create management challenges that need to be addressed. For that reason, this paper aims to investigate the challenges in respect to managing MPEs within the construction industry. It essentially reviews state-of-art knowledge in respect to MPEs identifying the rationale behind their development. At this stage it would appear that the interdependency and uncertainty within inputs, processes and outputs are major contributing factors to the MPE problem. It is of note that the majority of these findings were based within the context of developed countries. Hence, this review sets out to inform practitioners from developing countries in respect to lessons learned within more developed countries. This review is expected to lead to further investigations on MPEs and their inherent challenges.
\end{abstract}

Keywords: Construction industry, project management, multiple project environments

\section{Introduction}

Organisations are taking management initiatives by shifting the paradigm of project management to the management of multiple projects (Blomquist and Müller, 2006, Pennypacker and Dye, 2002, Evaristo and van Fenema, 1999) as an efficient vehicle to successfully deliver improvements and changes due to the unpredictable economic climate (Shehu and Akintoye, 2010). For the construction industry, it needs to assimilate new steps to intervene with such uncertainties to survive. Thus managers are altering their strategic direction to expand opportunities and expand capacity for marketing, sourcing, introducing new infrastructure and taking advantage of distributed location (Dooley et al., 2005).

Studies on the management of multiple projects are dominated by the high technology industry (Caniëls and Bakens, 2011, Patanakul and Milosevic, 2009, Maylor et al., 2006) specifically on the new product development. Few studies have examined and little analytical attention have been paid to the management of multiple projects environment within the construction industry (Gholipour, 2006, Blismas et al., 2004, Dubois and Gadde, 2002).

Furthermore, most studies have demonstrated the existence of multiple projects environment from the context of developed country. Although studies on construction industry in the context of developing country has been acknowledged in the literature (Ngowi, 2002, Ofori, 2000), little recognition has been given to the multiple project environments within the construction industry. It is important to recognise the management of multiple projects environment from the developing country because the construction industry among countries is different as presented in the cultural studies of the construction projects, firm and site by Baiden and Price (2011). Thus, the complexity of challenges will be different in the level of socio-economic stress, chronic resource shortages, institutional weaknesses and a general inability to deal with the key issues (Ofori, 2000).

Therefore, this review builds on and contributes to the work in the multiple projects environment (MPE) within the construction industry. Although studies in the MPE have examined the development of effectiveness in management (Chinowsky et al., 2011, i.e 
Patanakul and Milosevic, 2009), there has been lack of an extended study on the challenges that hinder the effectiveness in managing the MPE. This paper will address this issue by reviewing how the assertions about challenges attributed to the MPE within the construction industry have been transformed into lessons to be learned for the developing countries. Consequently, this review provides additional insight into the constructive processes of exploring challenges by explicating the challenges through which the uncertainty and interdependency is constructed from the complexity of management.

\section{Multiple project environments}

Multiple project environments (MPEs) have been defined in many ways in the research. To describe the management of MPEs, studies have been premised with terms such as multiproject, portfolio, programme, macro-project, mega-project, giving the impression of similar meanings (Turner, 2009, Project Management Institute, 2008). The inconsistency in definition has led to limited insights due to confusion and diverse understanding (Shehu and Akintoye, 2010, Milosevic, 2009) into the relationship of MPEs and their challenges. The definition of the MPE in this review reveals some features that best describe the nature of the construction industry. Initially, MPEs was referred to, "an organisational level environment in which multiple projects are managed concurrently" (Patanakul and Milosevic, 2009, p. 217). However, this definition needs to be extended not to focus only on more than one project managed simultaneously, but also at various locations (Evaristo and van Fenema, 1999), on the possibility of involvement from multiple organisations (Dubois and Gadde, 2002)

These two features of multiple projects at various locations and involves multiple organisations are important in defining MPEs. The first feature stressed on various locations because within the construction industry, projects are influenced by geographical location which includes international and domestic distribution whether in a local region or elsewhere. This distribution is due to the potential benefits of the physical location and where professionals are involved in the project operation location (Zavadskas et al., 2004). One project can be performed in several sites concurrently, as long as the correspondent actions share the same objectives (Evaristo and van Fenema, 1999). The management of these projects is assumed to be either centralised or distributed located in any of the sites or nodes. The challenge of project's location of multiple projects is related to the focus on the co-ordination mechanisms, with the option of either focusing on inter-site or boundary spanning across sites, or concentrate on intra-site or boundary spanning across projects (Hashim and Chileshe, 2012).

The second feature originated from the construction management which is complicated by several organisations involved in the supply chain. The organisations are also engaged in other projects in which they have to coordinate their activities and resources with different sets of organisations. This affiliation shows that an organisation is capable in managing more than one project simultaneously in the construction industry (Dubois and Gadde, 2002) and supports project-based structures (Söderlund, 2004). The increased use of projectbased structures defines the nature of multiple project environments with the involvement of multi-project organisations.

From these features, the representation of challenges instigated from the complexity in managing multiple projects could be illustrated. For example, the projects located in multiple locations will focus on the co-ordination mechanisms, on single unit without segregating the projects into multiple units in sharing the projects goal and objectives even though they are widely distributed from each other (Desouza and Evaristo, 2004). On the other hand, projects which involves with multiple organisations will easily create conflict between the team mates, and impede the establishment of "organisation culture" of multiple projects environment particularly between different levels of management or between other projects,

Hashim, N.I., Chileshe, N., and Baroudi, B. (2012) 'Management challenges within multiple project environments: Lessons for developing countries', Australasian Journal of Construction Economics and Building, Conference Series, 1 (2) 21-31 
especially when competing after the same resources (Fricke and Shenbar, 2000, Olford, 2002). Therefore, these features illustrate the challenges in managing the MPE that will minimise the effectiveness in managing the projects. .

\section{Methods}

The focus of this paper is given to the research on the multiple projects management within the developed country. Therefore, little consideration will be given to the contributions within traditional project management, such as project risk management, project planning and etc. The attention is on studies and articles that analyse the complexity of multiple projects environment with its challenges in the management aspect and emphasis on the three major domains - inputs, process, and outputs of multiple project environments (Patanakul and Milosevic, 2009).

The review was carried out in several steps: analysis of earlier reviews; literature search in the above mentioned journals; preliminary analysis and collection of key cited articles; and further search for other published work by author. The keywords used were "multi projects", "multiple projects management", "management challenges" and "complexity". During the progress of review, the foundation of the articles was traced. The articles are scanned through to find the most important note of the paper. This was made based on either the author's clear positioning towards certain articles, or the most often cited references. The articles were well-organised according to importance and abstracts were read. When the article met the requirements of the study, the entire article will be read.

Moreover, citation tracking databases such as Scopus and Web of Knowledge are used to search for articles that have been referred to in the studies covered by the literature search and more information also gathered from scholarly books. Despite the limited scope of the literature search, the intention was mainly to support and improve the information and to use existing knowledge on multiple projects management literature as far as possible.

In order to investigate on the challenges in managing the multiple projects environment this paper has reviewed a number of articles from Project Management Journal, Journal of Manufacturing Technology Management, The Journal of High Technology Management Research, Journal of Engineering, Design and Technology, Journal of Civil Engineering and Management, International Journal of Project Management, IEEE Transactions on Engineering Management, Engineering, Construction and Architectural Management, Construction Management and Economics, and AACE International Transactions for the time period between 2000 - 2012. However, majority of the articles are from the International Journal of Project Management (IJPM) because the research published in the IJPM extensively cover a wide range of topics on multiple project environments (Söderlund, 2004).

\section{MPE Challenges}

Research into MPEs has been narrowly focused on the challenges within multiple project management. The ambiguous nature of the findings says more about the success factor within researching this complex subject than about the factors influencing the challenges in MPEs (Patanakul and Milosevic, 2009, Dietrich and Lehtonen, 2005, Cooke-Davies, 2002). The studies have supported a conclusion with common sense which assumed the understanding of challenges.

On the other hand, the research evidence to date has relied heavily on complexity in managing multiple projects that cause challenges in management (Caniëls and Bakens, 2011, Aritua et al., 2009). Complexity is not necessarily a new challenge, but an old challenge that is being increasingly recognised and accepted as a key to improving performance and understanding of management (Aritua et al., 2009). Multiple projects

Hashim, N.I., Chileshe, N., and Baroudi, B. (2012) 'Management challenges within multiple project environments: Lessons for developing countries', Australasian Journal of Construction Economics and Building, Conference Series, 1 (2) 21-31 
management is faced with more challenges than single project management due to the complexity of the environment and organisations related to processes and project lifecycle. The complexity arises from interdependence and uncertainty in management which is the most critical features of context in developing effectiveness in organisational management (Griffin et al., 2007).

Interdependence means that a decision or action by any individual or system may be affected by having different impacts related to other individuals or systems (Mitleton-Kelly, 2003). It is by having many aspects or phases that this decision or action is interrelated. Example of the forms of interdependence are task interdependence in which one job serves as input or output to another job and also interdependence between jobs or roles, team or organisations (Morgeson and Humphrey, 2008). However, there has been little evidence based on the interdependency in management. Further, little research attention has focused on the uncertainty that occurs in managing the multiple projects environment. Uncertainty in management reflects the unpredictability in the inputs, processes and outputs of work systems (Wall et al., 2002). By undertaking activities with lack of specification on comprehensive activity in projects, unfamiliarity of local resources and environment and lack of uniformity will therefore invite an unpredictable environment (de Orue et al., 2009). The organisation will be forced by these factors in meeting project deadlines to achieve higher organisational performance (Laslo and Goldberg, 2008) thus creating challenges for project managers responsible for the overall success of delivering projects (Martyn James et al., 2008).

So far the interaction between the complexity challenge and effectiveness in delivering projects within MPEs within the construction industry is not broadly discussed (Shehu and Akintoye, 2010), even though the acknowledgement on this issue is recognised in practice within the construction industry (Chinowsky et al., 2011, Görög, 2011, Bankvall et al., 2010, Dubois and Gadde, 2002). Conversely, the extensive research on this relationship is dominated by the broader management environment. Researchers (Grant and Parker, 2009, Morgeson and Humphrey, 2008, Griffin et al., 2007, Wall et al., 2002) believe that complexity from interdependence will determine the extent of work roles that are embedded in a broader social system and determine whether an individual is effective by managing their responsibilities individually within an organisation or needs support from broader social context of the organisation. In addition, complexity from uncertainty will determine whether an individual is effective by complying with the requirements of a work role or by adapting to and initiating change. Therefore, since both interdependence and uncertainty are increasing in the management of most organisations, it is especially important to pursue and develop perspectives in managing multiple projects within the construction industry.

\section{Inputs, Processes and Outputs}

According to Patanakul and Milosevic (2009) and Hashim and Chileshe (2012), the perspectives on multiple projects environment in the literature offers three related domains: inputs; process; and outputs within the management of multiple projects. By referring to the suggested domains, literature reviews are identified and categorised into the uncertainty and interdependency of challenges that are embedded in managing multiple projects.

\section{Organisational Inputs}

The organisational input of the MPE plays an important role to effectively managing the multiple projects. By organisational input, it is referred to the project selection and resource allocation that are influenced by the environmental context of the organisation. Researchers have recognised that project selection and resource allocation are intertwined with the uncertainty in management. Patanakul and Milosevic (2009) have examined the uncertainty in project selection that accentuated linkages with resource allocation in projects. In project

Hashim, N.I., Chileshe, N., and Baroudi, B. (2012) 'Management challenges within multiple project environments: Lessons for developing countries', Australasian Journal of Construction Economics and Building, Conference Series, 1 (2) 21-31 
selections, organisation should provide essential amount of resources as it is very ineffective to implement too many projects simultaneously without sufficient resources. In addition, the allocation of resources also brings another challenge to project manager (Elonen and Artto, 2003, Fricke and Shenbar, 2000). Lack of adequate resource allocations in every task and difficulty in sustaining resources will influence failure within the multiple projects environment (Patanakul and Milosevic, 2009, Fricke and Shenbar, 2000).

Similarly, Patanakul and Milosevic (2006) also assess the extent to which the selection involves the understanding of project priority as well as to match the ability of project manager with the project assignments. The challenge lies on the assignment of projects to project managers when the number of projects is greater than their ability to manage the projects at a time (John et al., 2000). Effective allocations of projects to the project manager should take into account the priority of a project and match the competencies of project manager with the project requirements recognising personal limitations (Patanakul et al., 2007, Patanakul and Milosevic, 2006, Meredith and Mantel, 2003).

\section{Management Processes}

In reviewing current literature, process issues in management are widely discussed and essentially related to uncertainty in the operational level focusing on the project manager. The issues look at the unpredictability in leading the group of projects as being important for effectiveness in management (Patanakul and Milosevic, 2008). Such issues focus on the need for problem solving, information sharing and multitasking typically in conjunction with shifting attention from project to project and responsibility among multiple teams (Patanakul and Milosevic, 2009). In the study by Engwall and Jerbrant (2003) uncertainty in problem solving is formed when the knowledge development is subordinate to solve the short term problem. With regards to information sharing, lack of information delivery within stakeholders will increase in uncertainty (Elonen and Artto, 2003). Besides that, multitasking is demanding in dealing among different issues of different projects that have different goals and characteristics (Patanakul and Milosevic, 2008). In addition, effective communication is about exchanging meaningful information and knowledge among projects and project team to influence thinking and encourage subsequent actions (Lycett et al., 2004). However, good communication is hard to achieve when managing multiple simultaneous projects, thus anticipate challenges in circulating information and knowledge within project processes.

In management processes, interdependency possesses the highest stake. Interdependency represents challenge during the process of implementation and practice stages of construction projects, as the alignment, planning, coordination and execution of the management of single projects in MPEs are carried out with a high level of precision (Shehu and Akintoye, 2010). This stage is critical because the greater the interdependence between processes, the wider the agitation or disturbance of an action by one process on all the other related processes (Mitleton-Kelly, 2003). Elonen and Artto (2003) found that managing multiple internal developments projects is one of the problems. This problem can be seen in terms of the classical concept of project management which includes plan-docheck-action cycles, organisation breakdown structure and work breakdown structures (Hashim and Chileshe, 2012). Hence, any adjustment to schedules or resources which relates to these project management concepts complicates the management of projects due to associated changes among tasks (Patanakul and Milosevic, 2009, Danilovic and Sandkull, 2005, Lycett et al., 2004). In addition, the inter-project interaction becomes an issue when interdependency in MPEs is presented. When one project is under this interaction problems it leads to delay (Fricke and Shenbar, 2000), which affects other projects in return and coordination for align projects to strategy (Milosevic, 2009) as MPEs comprise of projects that are interrelated.

Hashim, N.I., Chileshe, N., and Baroudi, B. (2012) 'Management challenges within multiple project environments: Lessons for developing countries', Australasian Journal of Construction Economics and Building, Conference Series, 1 (2) 21-31 


\section{Project Outputs}

Typically, a key reason that an organisation implements the MPE is to achieve better efficiency and management of projects. MPE can only be effectively managed in any organisation if there is certainty in project manager's expectation and the project's benefits. The expected output from project managers are meeting time, cost, performance, and satisfying customers and effective use of organisational resources (Patanakul and Milosevic, 2009, John et al., 2000). In the meantime, the project's benefits should be established in the form of potential of project output (Shehu and Akintoye, 2010). Uncertainty about a project's output and benefit can let other projects take priority attention that is not favourable for effectiveness in managing multiple projects.

\section{Discussion}

Overall, the emerging perspective on challenges provides important insights into the effectiveness in managing the MPE. This literature review has recognised the attributes of MPEs, which is the management of multiple projects simultaneously (Patanakul and Milosevic, 2009). An example is the assignment of a residential construction project, building construction project and an alteration or improvement of facilities project to one project manager. It also has identified additional attributes of MPE which should be considered to describe the nature of construction industry. One new attribute is the management of multiple projects in multiple locations (Desouza and Evaristo, 2004). One project could be in different region, states, or even country to require benefits from different locations such as close cooperation of professionals or to take advantage of the location. Another attribute is the involvement of multiple organisations that connect stakeholders' actions to the development of projects organisation (Dubois and Gadde, 2002). For example, in one project many organisations are all involved in operations at a construction site which contribute to the resources of various kinds. The organisations also involve in other projects that might cooperate with similar or other organisations. Therefore, each organisation needs to consider different dimensions of co-ordination within the individual project, among different construction projects and inter-firm coordination with other projects.

These attributes should be considered as conditions and moderators of challenges in managing multiple projects. These moderators are uncertainty and interdependency of management that shaped the complexity of the environment (Grant and Parker, 2009) which influence on the organisational input, management processes and output of projects (Hashim and Chileshe, 2012, Patanakul and Milosevic, 2009). Organisational input is the earliest process of the project lifecycles which involves in the initiation or conceptual of the project (Patanakul et al., 2010). The outcomes of uncertainty in the organisational input include project selection in understanding the project priority, matched with the ability of project managers and the project assignments and resource allocation. The management processes is the continuing process throughout the projects which support monitoring and control activities (Project Management Institute, 2008). Uncertainty in the management process takes account of effective communication, leading groups of projects in resolving problems, information sharing and multitasking. While the project output is looking into the overall success of the projects (Patanakul et al., 2010) focus on the project manager's expectations and project benefits.

However, interdependency mainly occurs in the process stage focused on driving the execution of projects (Project Management Institute, 2008) where single projects are manage simultaneously follow by inter-project interactions. Interdependency is important in project management processes for adjusting and linking schedules to match available resources, and removing unnecessary variation in workloads of project managers. Table 1 summarise the discussion on the challenges in the MPE.

Hashim, N.I., Chileshe, N., and Baroudi, B. (2012) 'Management challenges within multiple project environments: Lessons for developing countries', Australasian Journal of Construction Economics and Building, Conference Series, 1 (2) 21-31 
Table 1: Summary of the literature related to the challenges in MPEs

\begin{tabular}{|c|c|c|}
\hline MPE / Challenges & Uncertainty & Interdependency \\
\hline $\begin{array}{c}\text { Organisational } \\
\text { Input }\end{array}$ & $\begin{array}{l}\text { Project selection } \\
\text { (Patanakul and Milosevic, 2009) } \\
\text { To understand the project priority, } \\
\text { match between the ability of project } \\
\text { managers and the project assignments } \\
\text { Resource allocation } \\
\text { (Elonen and Artto, 2003, Fricke and } \\
\text { Shenbar, 2000) }\end{array}$ & \\
\hline $\begin{array}{l}\text { Management } \\
\text { Processes }\end{array}$ & $\begin{array}{l}\text { Lead group of projects (Patanakul and } \\
\text { Milosevic, 2009, Patanakul and } \\
\text { Milosevic, 2008) } \\
\text {-Problem solving } \\
\text { (Engwall and Jerbrant, 2003) } \\
\text {-Information sharing } \\
\text { (Elonen and Artto, 2003) } \\
\text {-Multitasking } \\
\text { (Patanakul and Milosevic, 2008) } \\
\text { Communication } \\
\text { (Lycett et al., 2004) }\end{array}$ & $\begin{array}{l}\text { Management of single projects } \\
\text { (Shehu and Akintoye, 2010) } \\
\text {-Project Management Process } \\
\text { (Hashim and Chileshe, 2012) } \\
\text { To adjust and link } \\
\text { schedules to match available } \\
\text { resources, and remove } \\
\text { unnecessary variation in } \\
\text { workloads of project managers } \\
\text { Inter-project interactions } \\
\text { (Milosevic, 2009, Fricke and } \\
\text { Shenbar, 2000) }\end{array}$ \\
\hline Project Output & $\begin{array}{l}\text { Project manager's expectation } \\
\text { (Patanakul and Milosevic, 2009, John } \\
\text { et al., 2000) } \\
\text { Project's benefit } \\
\text { (Shehu and Akintoye, 2010) }\end{array}$ & \\
\hline
\end{tabular}

\section{Contribution}

From a theoretical point of view this literature review broadened the project management knowledge in respect to relationships within multiple projects environments and their challenges. The identification of the challenges should be of interest to researchers within risk management in respect to multiple projects environments and this should be recognised as being an essential part of the construction industry. The practical contribution of this study would be through the exploration of challenges in the multiple projects environment that are

Hashim, N.I., Chileshe, N., and Baroudi, B. (2012) 'Management challenges within multiple project environments: Lessons for developing countries', Australasian Journal of Construction Economics and Building, Conference Series, 1 (2) 21-31 
likely to confront project managers. It should be kept in mind that project management is a core competence and the building of project capabilities thus this exploration is assisting in identifying and mitigating the future risks in managing multiple projects. It also aims to improve the effectiveness and efficiency of project managers by providing findings that serve as a basis for developing strategies within organisational management.

Moreover, in light of globalisation, national and organisational cultures may play an increasingly important role in the MPE development. Within the context of developed countries a comparison guideline should be formulated for the management of multiple projects. National and organisational cultures can play an important role in influencing the challenges in MPEs. However, the lack of in-depth knowledge of how the global environment and the differences in cultures across societies and organisations affect MPEs thus creates challenges that hinder the effectiveness of management. Therefore, it is hoped that this study will inspire other researchers to provide understandings for the development of MPEs not only within the context of developed countries but also for the developing world.

\section{Conclusions}

The unpredictability of the current economic climate has directed the development of MPEs. Most studies on MPEs focus on newly development products from the manufacturing industry where the processes are mainly high risk with concurrent processes. However, in the construction industry, the MPE is part of the inherent nature of industry practice, albeit with a lack of research that establishes the understanding of the phenomena. At this stage, project management practice in MPEs has not adopted an explicit way to identify and select the right management style. This study suggests that the understanding of challenges will give rise to adopting the right approach for the right project.

The trends of increasing interdependence and uncertainty in managing projects are emerging which creates challenges for managing the MPE effectively. Ultimately, there is a need for better understanding of challenges in supporting the development of effective management. To achieve this understanding, it may be necessary to consider the various perspectives and challenges in parallel. These advances in MPE research are beginning to answer calls to investigate the challenges and its implications for management. Even though this study applies only to a subset of organisations and industries, challenges in MPEs are relevant to understand and change the experiences and behaviours of managers within the project management discipline.

In summary, what is missing at this point is a comprehensive framework of the challenges and effectiveness in managing the MPE. The need of a management framework is to capture the overall characteristics of the MPE in the construction industry. It will also assist in identifying conditioning variables that influence the relationship and the outcomes they influence, and a core set of mediators and moderators for these relationships. The evidence reviewed above not only aims to provide a platform of progressing into empirical research within developed countries but also as a function of lessons learned to develop a comprehensive study on the development of multiple projects environments within developing nations.

\section{References}

Aritua, B., Smith, N. J. \& Bower, D. 2009. Construction client multi-projects - A complex adaptive systems perspective, International Journal of Project Management, vol. 27, no. 1, pp. 72-79.

Baiden, B. K. \& Price, A. D. F. 2011. The effect of integration on project delivery team effectiveness, International Journal of Project Management, vol. 29, no. 2, pp. 129-136.

Hashim, N.I., Chileshe, N., and Baroudi, B. (2012) 'Management challenges within multiple project environments: Lessons for developing countries', Australasian Journal of Construction Economics and Building, Conference Series, 1 (2) 21-31 
Bankvall, L., Bygballe, L. E., Dubois, A. \& Jahre, M. 2010. Interdependence in supply chains and projects in construction, Supply Chain Management: An International Journal, vol. 15, no. 5, pp. 385393.

Blismas, N., G. , Sher, W., D. , Thorpe, A. \& Baldwin, A., N. 2004. Factors influencing project delivery within construction clients' multi-project environments, Engineering, Construction and Architectural Management, vol. 11, no. 2, pp. 113 - 125.

Blomquist, T. \& Müller, R. 2006. Practices, roles, and responsibilities of middle managers in program and portfolio management Project Management Journal, vol. 37, no. 1, pp. 52-66.

Caniëls, M. C. J. \& Bakens, R. J. J. M. 2011. The effects of project management information systems on decision making in a multi project environment, International Journal of Project Management, vol. 30, no. 2, pp. 162-175.

Chinowsky, P., Taylor, J. E. \& Di Marco, M. 2011. Project network interdependency alignment: new approach to assessing project effectiveness, Journal of Management Engineering, vol. 27, no. 3, pp. 170-178.

Cooke-Davies, T. 2002. The "real" success factors on projects, International Journal of Project Management, vol. 20, no. 3, pp. 185-190.

Danilovic, M. \& Sandkull, B. 2005. The use of dependence structure matrix and domain mapping matrix in managing uncertainty in multiple project situations, International Journal of Project Management, vol. 23, no. 3, pp. 193-203.

de Orue, D. A. O., Taylor, J. E., Chanmeka, A. \& Weerasooriya, R. 2009. Robust project network design, Project Management Journal, vol. 40, no. 2, pp. 81-93.

Desouza, K. C. \& Evaristo, J. R. 2004. Managing knowledge in distributed projects, Communication of the ACM, vol. 47, no. 4, pp. 87-91.

Dietrich, P. \& Lehtonen, P. 2005. Successful management of strategic intentions through multiple projects - Reflections from empirical study, International Journal of Project Management, vol. 23, no. 5, pp. 386-391.

Dooley, L., Lupton, G. \& Sullivan, D. O. 2005. Multiple project management: a modern competitive necessity, Journal of Manufacturing Technology Management, vol. 16, no. 5/6, p. 466.

Dubois, A. \& Gadde, L.-E. 2002. The construction industry as a loosely coupled system: Implications for productivity and innovation, Construction Management and Economics, vol. 20, no. 7, pp. 621631.

Elonen, S. \& Artto, K. 2003. Problems in managing internal development projects in multi-project environments, International Journal of Project Management, vol. 21, no. 6, pp. 395-402.

Engwall, M. \& Jerbrant, A. 2003. The resource allocation syndrome: The prime challenge of multiproject management, International Journal of Project Management, vol. 21, no. 6, pp. 403-409.

Evaristo, R. \& van Fenema, P. C. 1999. A typology of project management: Emergence and evolution of new forms, International Journal of Project Management, vol. 17, no. 5, pp. 275-281.

Fricke, S. E. \& Shenbar, A. J. 2000. Managing multiple engineering projects in a manufacturing support environment, IEEE Transactions on Engineering Management, vol. 47, no. 2, pp. 258-268.

Gholipour, Y. 2006. 'Multi-Project Resources Procurement in the Construction Industry', in McDermott, P. \& Khalfan, M. M. A., eds., Sustainability and Value Through Construction Procurement, Salford, United Kingdom, 29 November - 2 December 2006, Salford Centre for Research and Innovation (SCRI), University of Salford, pp. 172-181.

Görög, M. 2011. Translating single project management knowledge to project programs, Project Management Journal, vol. 42, no. 2, pp. 17-31.

Grant, A. M. \& Parker, S. K. 2009. Redesigning work design theories: The rise of relational and proactive perspectives, ACADEMY OF MANAGEMENT ANNALS, vol. 3, no. 1, pp. 317-375.

Hashim, N.I., Chileshe, N., and Baroudi, B. (2012) 'Management challenges within multiple project environments: Lessons for developing countries', Australasian Journal of Construction Economics and Building, Conference Series, 1 (2) 21-31 
Griffin, M. A., Neal, A. \& Parker, S. K. 2007. A new model of work role performance: Positive behavior in uncertain and interdependent contexts, Academy of Management Journal, vol. 50, no. 2, pp. 327347.

Hashim, N. I. \& Chileshe, N. 2012. Major challenges in managing multiple project environments (MPE) in Australia's construction industry, Journal of Engineering, Design and Technology, vol. 10, no. 1, pp. 72-92.

John, A. K., Chung-Li, J., Abdallah, S. F. \& Wahib, G. J. 2000. Project manager workload-assessment of values and influences, Project Management Journal, vol. 31, no. 4, p. 44.

Laslo, Z. \& Goldberg, A. I. 2008. Resource allocation under uncertainty in a multi-project matrix environment: Is organizational conflict inevitable?, International Journal of Project Management, vol. 26, no. 8, pp. 773-788.

Lycett, M., Rassau, A. \& Danson, J. 2004. Programme management: a critical review, International Journal of Project Management, vol. 22, no. 4, pp. 289-299.

Martyn James, H., Paul William, F., Martin, S., Carol, K. H. H. \& Patrick Sik-Wah, F. 2008. 'The Role of Project Managers in Construction Industry Development', AACE International Transactions, DE141DE149.

Maylor, H., Brady, T., Cooke-Davies, T. \& Hodgson, D. 2006. From projectification to programmification, International Journal of Project Management, vol. 24, no. 8, pp. 663-674.

Meredith, J. R. \& Mantel, S. J. 2003. Project Management A Managerial Approach, 5th ed., New Jersey: John Wiley \& Sons Inc.

Milosevic, D. Z. 2009. Program management for improved business results, New Jersey: Wiley.

Mitleton-Kelly, E. 2003. Complex systems and evolutionary perspectives on organisations: the application of complexity theory to organisations, Amsteradm: Pergamon.

Morgeson, F. \& Humphrey, S. 2008. Job and team design: Toward a more integrative conceptualization of work design, Research in Personnel and Human Resources Management, vol. 27, no. Journal Article, pp. 39-91.

Ngowi, A. 2002. Challenges facing construction industries in developing countries, Building Research \& Information, vol. 30, no. 3, pp. 149-151.

Ofori, G. 2000. 'Challenges of construction industries in developing countries: Lessons from various countries', in Proceedings of the 2nd international conference in developing countries: challenges facing the construction industry in developing countries, Gabarone, Botswana, 15-17 November 2000.

Olford, W. J. 2002. 'Why is multiple project management hard and how can we make it easier?' in Pennypacker, J. S. \& Dye, L. D., eds., Managing multiple projects: planning, scheduling and allocating resources for competitive advantage, New York: Marcel Dekker, Inc.

Patanakul, P., lewwongcharoen, B. \& Milosevic, D. 2010. An empirical study on the use of project management tools and techniques across project life-cycle and their impact on project success, Journal of General Management, vol. 35, no. 3, p. 41.

Patanakul, P. \& Milosevic, D. 2006. Assigning new product projects to multiple-project managers: What market leaders do, The Journal of High Technology Management Research, vol. 17, no. 1, pp. 53-69.

Patanakul, P. \& Milosevic, D. 2008. A competency model for effectiveness in managing multiple projects, The Journal of High Technology Management Research, vol. 18, no. 2, pp. 118-131.

Patanakul, P. \& Milosevic, D. 2009. The effectiveness in managing a group of multiple projects: Factors of influence and measurement criteria, International Journal of Project Management, vol. 27, no. 3, pp. 216-233.

Patanakul, P., Milosevic, D. \& Anderson, T. 2007. A decision support model for project manager assignments, IEEE Transactions on Engineering Management, vol. 54, no. 3, p. 548.

Hashim, N.I., Chileshe, N., and Baroudi, B. (2012) 'Management challenges within multiple project environments: Lessons for developing countries', Australasian Journal of Construction Economics and Building, Conference Series, 1 (2) 21-31 
Pennypacker, J. S. \& Dye, L. D. 2002. 'Project portfolio management and managing multiple projects: Two sides of the same coin' in PENNYPACKER, J. S. \& Dye, L. D., eds., Managing multiple projects: planning, scheduling and allocating resources for competitive advantage, New York: Marcel and Dekker Inc, 1-10.

Project Management Institute 2008. A guide to the project management body of knowledge (PMBOK® Guide), Newtown Square, Pennsylvania: Project Management Institute, Inc.

Shehu, Z. \& Akintoye, A. 2010. Major challenges to the successful implementation and practice of programme management in the construction environment: A critical analysis, International Journal of Project Management, vol. 28, no. 1, pp. 26-39.

Söderlund, J. 2004. On the broadening scope of the research on projects: a review and a model for analysis, International Journal of Project Management, vol. 22, no. 8, pp. 655-667.

Turner, J. R. 2009. The handbook of project-based management: leading strategic change in organizations, 3rd ed. ed., New York: McGraw-Hill.

Wall, T. D., Cordery, J. L. \& Clegg, C. W. 2002. Empowerment, performance, and operational uncertainty: A theoretical integration, Applied Psychology An International Review, vol. 51, no. 1, pp. 146-146.

Zavadskas, E. K., Ustinovichius, L. \& Stasiulionis, A. 2004. Multicriteria valuation of commercial construction projects for investment purposes, Journal of Civil Engineering and Management, vol. 10, no. 2, pp. 151-166.

Hashim, N.I., Chileshe, N., and Baroudi, B. (2012) 'Management challenges within multiple project environments: Lessons for developing countries', Australasian Journal of Construction Economics and Building, Conference Series, 1 (2) 21-31 